\title{
Synthesis of Plant Mediated Metal Nanoparticle and Assessment of Its Antibacterial Activity
}

\author{
R. Christynal Oliviya \\ Assistant Professor, Department of Biotechnology, Lady Doak College, Madurai 625002, \\ christynaloliviya@ldc.edu.in
}

\begin{abstract}
A laboratory experiment was conducted in order to examine the effect of phytochemicals in the form of nanoparticle as an anti-bacterial agent. This study focuses on effectiveness of silver nanoparticle in the treatment of diseases caused by bacterial infection. For this, the phytochemicals present in the plant Abelmoschus esculentus was analysed and they were estimated. The justified amount of phytochemicals present in this plant gave an interest to produce nanoparticle using $\mathrm{AgNo}_{3}$ in order to enhance its anti-bacterial property as they exhibit larger surface area to volume ratio. Then, the green synthesised silver nanoparticle was confirmed and the anti- bacterial activity also performed by disc diffusion method. This study reveals that the plant the Abelmoschus esculentus has good antibacterial activity which shows better result when they were in a nanoscale than in bulk scale.
\end{abstract}

Keywords: Abelmoschus esculentus, HPLC, silver nanoparticle, UV spectrophotometer, anti-bacterial activity

\section{INTRODUCTION}

Plants have always been an exemplary source of drugs and many of the currently available drugs have been derived directly or indirectly from them. A wide array of plant derived active principles representing numerous chemical compounds has demonstrated activity consistent with their possible use in the treatment of various diseases[7]. These medicinal properties of the plant extract can be enhanced with nano silver and it could play vital role in treatment of many diseases (Akhil Gupta et al., 2011; Shreesh Kumar Ojha and Dharamvir Singh Arya 2011).

Now- a-days, biosynthesis of nanoparticle by the plants extract is also currently under exploitation. The development of biologically inspired experimental processes for the synthesis of nanoparticle is evolved into an important branch of nanotechnology (Murphy, 2008). The silver nanoparticles (nano-Ag) have proved to be most effective as they exhibit potent antimicrobial efficacy against bacteria, viruses and eukaryotic micro-organisms [8]. The bacteriocidal properties of silver nanoparticles are due to the release of silver ions from the particles, which confers the antimicrobial activity. Besides, the potency of the antibacterial effects corresponds to the size of the nanoparticle. The smaller particles have higher antibacterial activities due to the equivalent silver mass content.

Thus, the present study focuses on the evaluation of phytochemicals present in Abelmoschus esculentus (L) Moench and their enhanced antimicrobial activity along with silver when they converted into nanoparticle.

\section{MATERIALS AND METHODS}

\section{Sample Collection and Authentication of Plant material}

The fruits ofAbelmoschusesculentus were collected from Melur Village in Madurai District. Authentication of plant was carried out.

Extraction of mucilage (RishabhaMalviya, 2011) Abelmoschusesculentusfruits were used for isolation of mucilage. Fruits were washed with water to remove dirt. The seeds were removed and finely chopped and crushed into a mixer. The crushed fruit material was soaked in warm water for $4 \mathrm{~h}$, boiled for $2 \mathrm{~h}$ and kept aside for $2 \mathrm{~h}$ for release of mucilage into water. The material was squeezed in a muslin bag to remove the mark from the filtrate. The filtrate was used for further study.

\section{Phytochemical Analysis (Harbone, 1981)}

\section{(i) Qualitative Analysis}

Alkaloids,Tannins, Saponins, Steroids, Flavanoids, Glycosides and Amino acids were analyzed qualitatively.

\section{(ii) Confirmation of Phytochemicals by HPLC}

Results of biochemical analysis were further tested through HPLC analysis to confirm the presence of phytochemicals in the extract.

\section{iii) Quantitative analysis}

Once the presence of phytochemicals were confirmed, their amount in the plant extract was also analyzed by various standard methods. Such as Flavonoids-Libermamn by Burchard et al., Saponins by Brunner 1984, Vitamin C by Iodine method,Tannins by Van Burden and Robinson1981

Green Synthesis of Silver Nanoparticle( Govindaraju K et al., 2010) 
To $5 \mathrm{ml}$ of plant extract, $100 \mathrm{ml}$ of $1 \mathrm{mM} \mathrm{AgNo3}$ in $250 \mathrm{ml}$ Erlenmeyer flask. Flasks were kept in a shaker at $200 \mathrm{rpm}$ for 10 minutes [pH of the solution was maintained as slightly acidic (6.5-6.8)] incubated at room temperature for7hours. The colour change was observed.

\section{Confirmation of synthesized Silver Nanoparticle} (i) UV-Visible spectral analysis ( Klulkarniet al., 2011)

To $0.2 \mathrm{ml}$ of the suspension, $2 \mathrm{ml}$ of double distilled water was added and measured at $200 \mathrm{~nm}$ in UVVIS Spectrophotometer.

\section{ANTIBACTERIAL ACTIVITY OF ABELMOSCHUS ESCULENTUS (Mishra et al., 2010) \\ Disc diffusion method (Kirby Bauer method)} $1.3 \mathrm{~g}$ of nutrient agar was mixed with the double distilled water and allowed to sterilize by autoclaving it under 120psi pressure. The autoclaved agar was poured into sterile petriplates (Control, E.Coli and Bacillus subtillus) and kept for solidification[1]. After few minutes, the bacterial cultures such as E.coli, Bacillus subtillus, (3 hours old) was inoculated by using spread plate method and let it free for 3-4 minutes, then discs which were dipped into both Abelmoschus esculentus extract and plant mediated silver nanoparticle solution were placed on the agar plates. They were incubated at $37^{\circ} \mathrm{C}$. The zones of inhibitions by plant extract as well as silver nanoparticle in both bacterial cultures were observed.

Determination of minimum inhibitory concentration (Eloff J.N, 1998)

Antibacterial activity of both plant extract and silvern nanoparticle was also studied using minimum inhibitory concentration test. About 50 $\mu 1$ of mucilage was serially diluted with PBS saline with a initial concentration of $200 \mathrm{ml} / \mathrm{ml}, 400 \mathrm{ml} / \mathrm{ml}, 600 \mathrm{ml} / \mathrm{ml}$ in a 96 well micro titer plate and $50 \mu 1$ of 3hour old culture was added to each well separately. The microplate was covered and incubated at $37^{\circ} \mathrm{C}$ for 18 hours. Then, $40 \mu \mathrm{l}$ of $0.2 \mathrm{mg} / \mathrm{ml}$ of methyltetrazolium was added to each well and incubated for minutes. The appearance of violet colour in the wells indicates the growth of bacterial culture. The lowest concentration of extract that completely inhibited the growth was considered as the MIC values.

\section{RESULT AND DISCUSSION}

Table: 1 Qualitative Analysis of Phytochemicals

\begin{tabular}{|l|c|}
\hline TEST & RESULT \\
\hline Steroids & - \\
\hline Flavonoids & + \\
\hline Vitamin C & + \\
\hline Alkaloids & - \\
\hline Glycosides & - \\
\hline Tannins & + \\
\hline Saponins & + \\
\hline
\end{tabular}

When the plant extract was examined for the presence of phytochemicals, the results showed that the phtochemicals such as flavanoids, tannins saponins and vitamin $\mathrm{C}$ were present.

Area \% Report

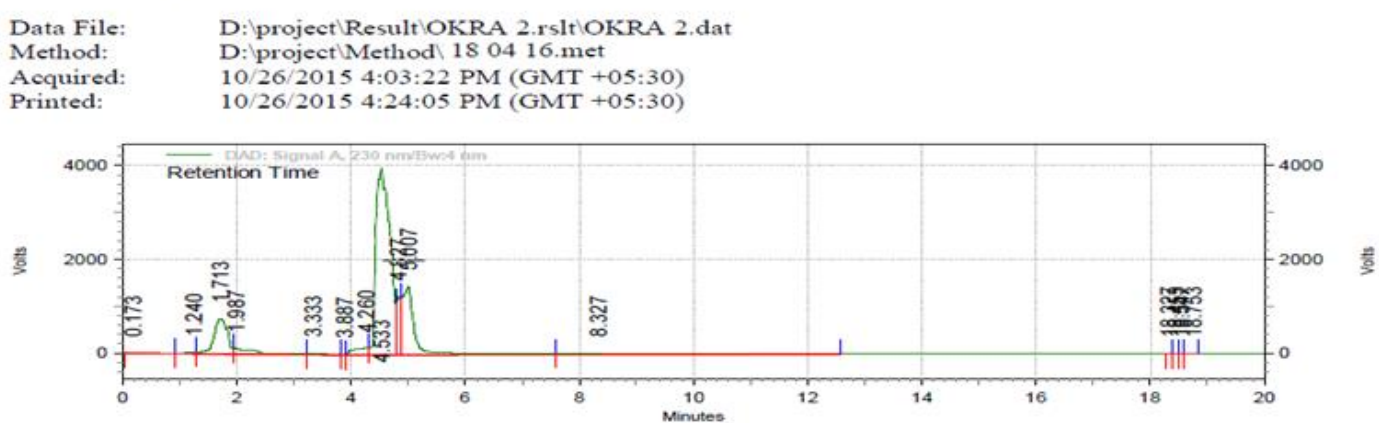

Fig: 1 Confirmation of Phytochemicals by HPLC

The chromatogram of HPLC at $250 \mathrm{~nm}$ showed the presence of two peaks for the plant extract. Thus the presence of secondary metabolite in the plant extract was confirmed by HPLC method. 
Available online at www.ijrat.org

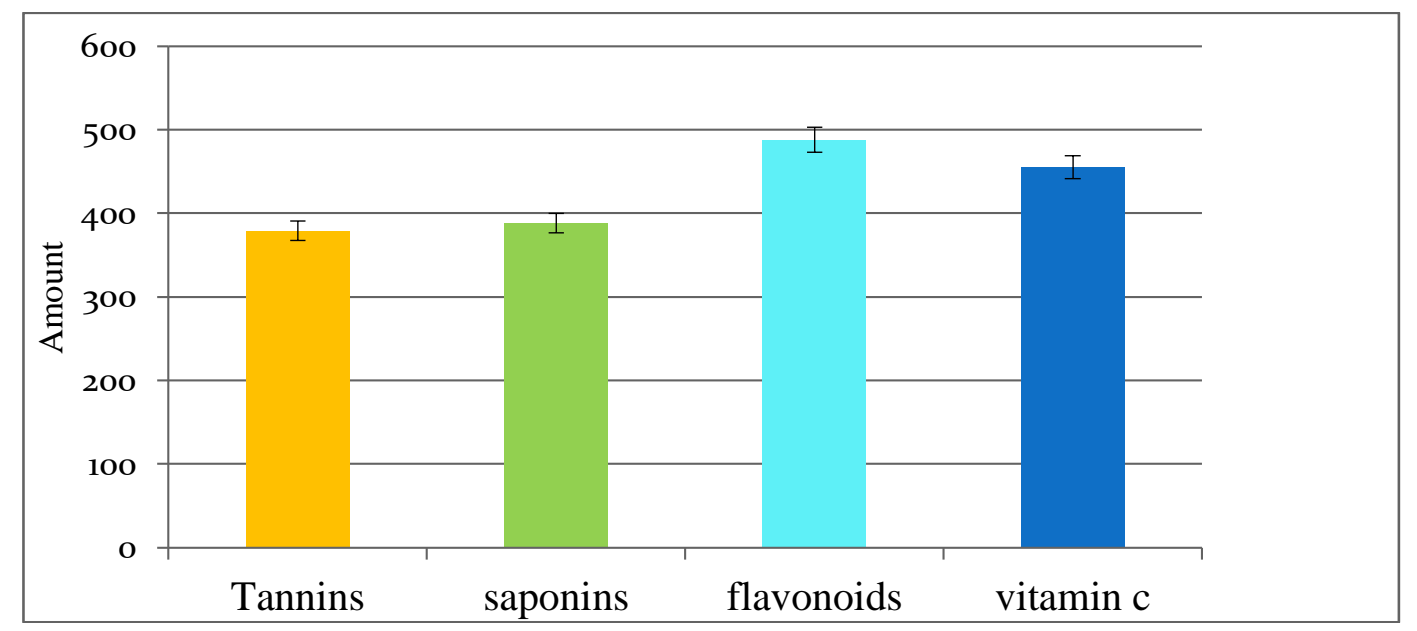

Fig: 2 Quantitative Analysis of Phytochemicals

The quantitative analysis of phytochemicals shows that the flavonoids are in higher level than tannins and saponins which are approximately equal in their amounts. The amount of Vitamin $\mathrm{C}$ is higher than tannin and saponin but lesser than flavonoids.
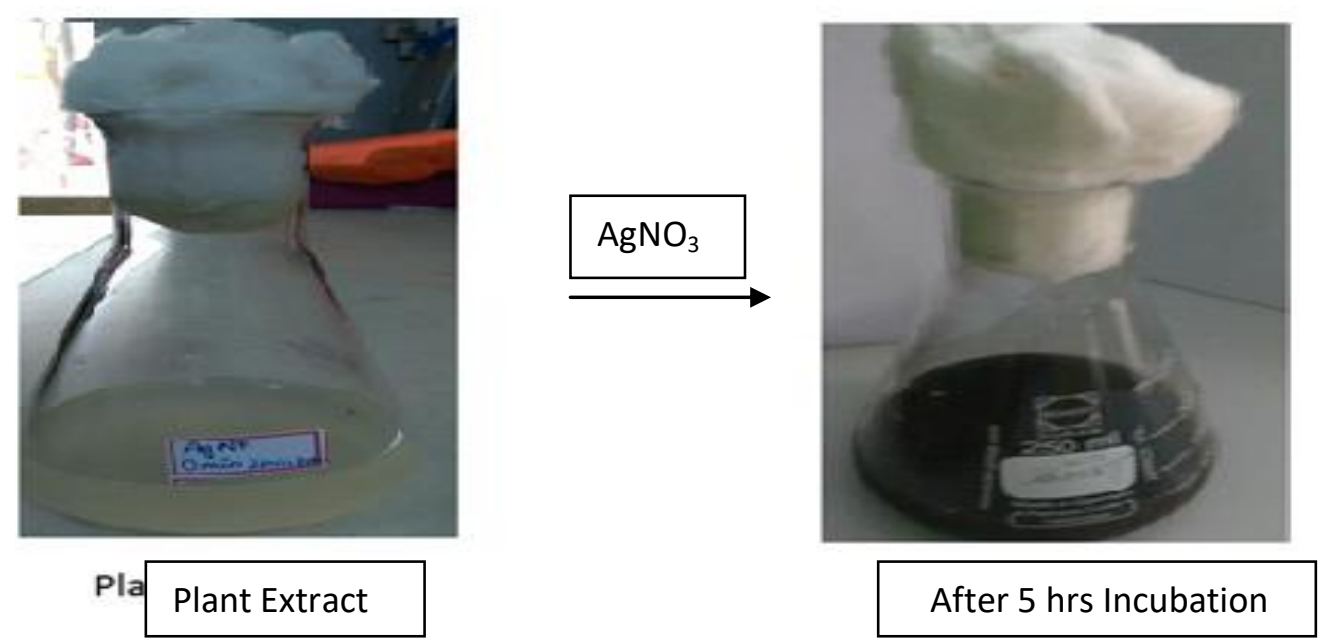

Fig: 3 Geen synthesis of silver nanoparticle

Before the addition of $\mathrm{AgNO}_{3}$ the colour of the plant extract was pale yellow but after the treatment with $\mathrm{AgNO}_{3}$, it has been changed in to dark brown which indicates the formation of silver nanoparticle.

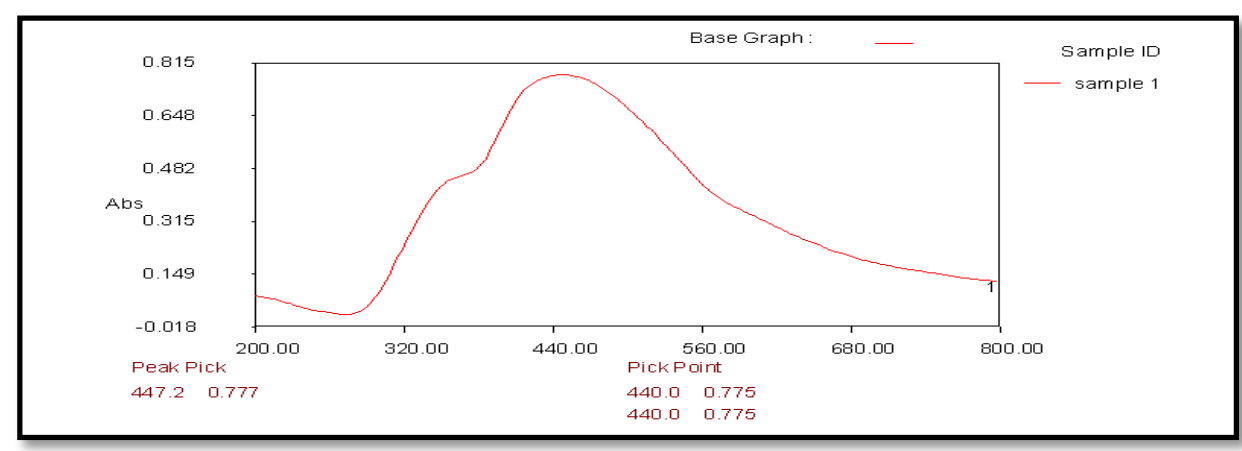

Fig: 4 UV-Visible spectroscopy

UV- Visible absorption peak of synthesized nanoparticle was observed approximately at 360 to $420 \mathrm{~nm}$. The spectrum shows the formation of spherical AgNP of the plant extract. 
Plate.1: Bacillus subtillus against AgNPs

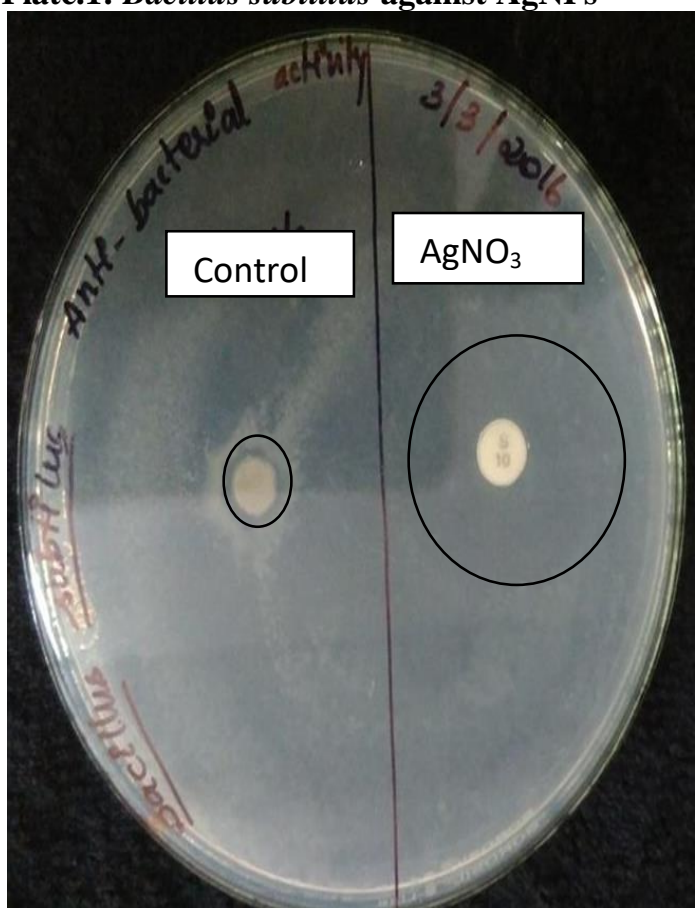

Plate.3:E.coli against Plant extract

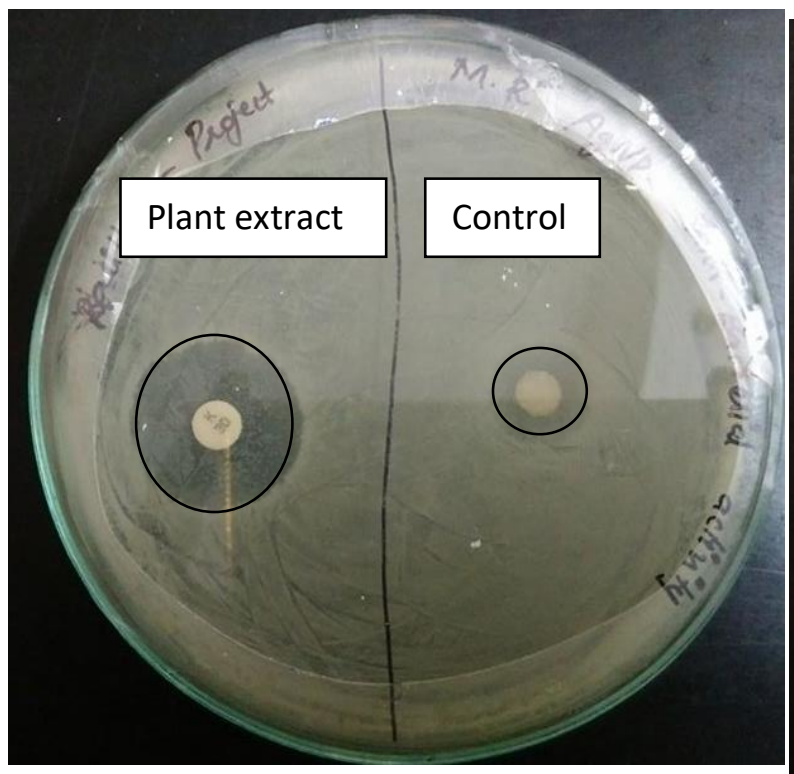

The anti-bacterial activity of plant (Abelmoschus esculentus (L) Moench) extract and its silver nanoparticles were examined by disc diffusion method against bacterial strains such as Bacillus subtilis and E.coli. Both bacerias were showed zone of inhibitions against plant extract and the nanoparticle synthesised from it. The competent zones of inhibitions were observed in silver nanoparticle synthesized from the plant.

\section{CONCLUSION}

The present study concluded that the plant Abelmoschus esculentus has anti-bacterial activity.

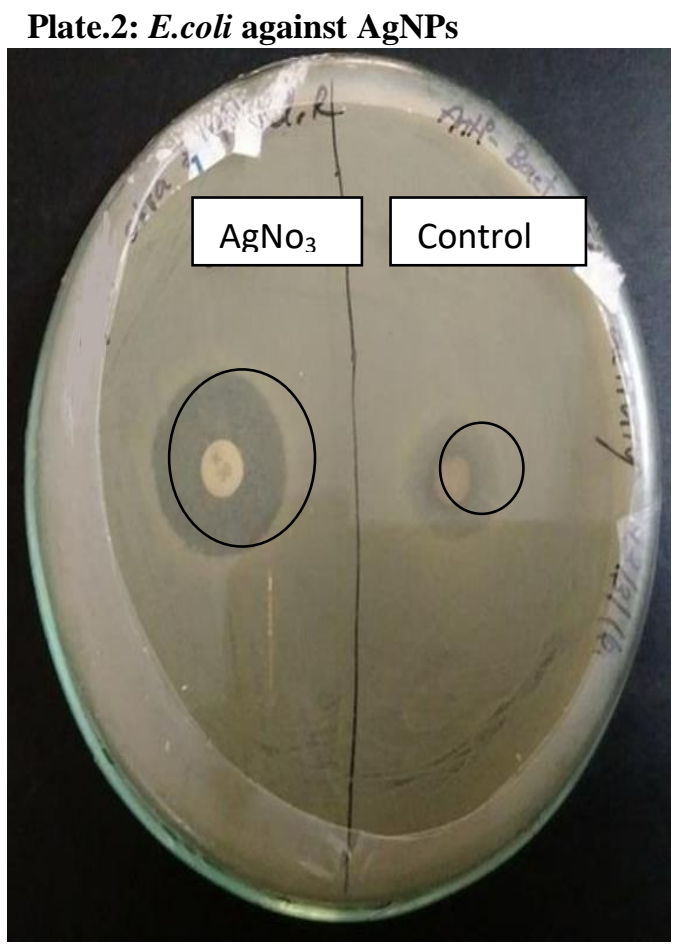

4: Bacillus subtills against Plant extract

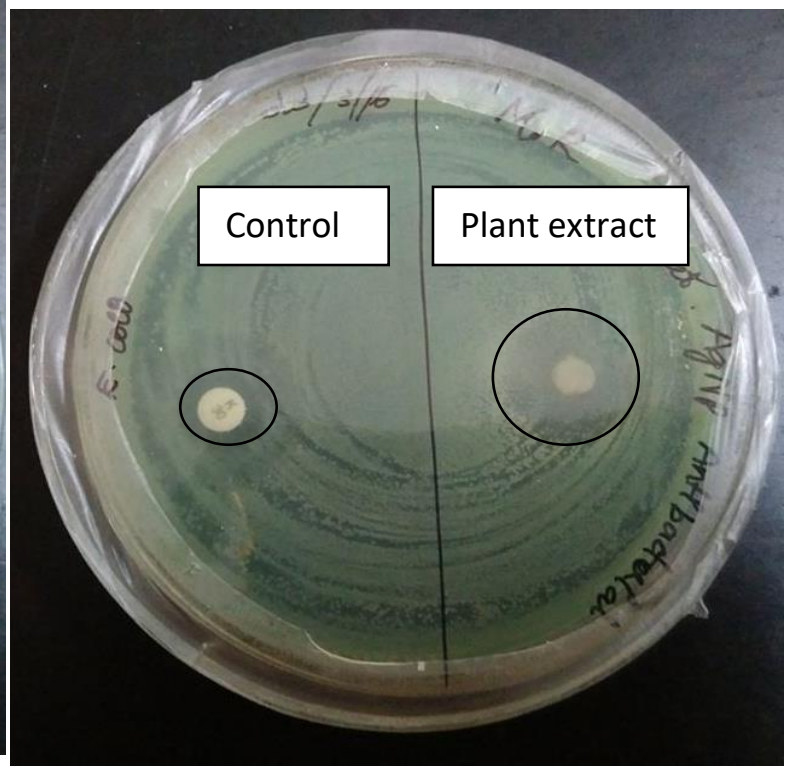

At the same time, when the plant extract was converted into nanoparticle, its anti-bacterial efficiency was enhanced. Hence, the study suggests that the medicinal properties of the plant will give an improvised result if they were in nano size.

\section{ACKNOWLEDGEMENT}

I am grateful to Ms. Rekha who helped for this study.

\section{REFERENCES}

[1] Aladesanmi AJ, Iwalewa EO, Adebajo AC, Akinkunmi EO, Taiwo BJ, Olorunmola FO, 
Lamikanra A (2007). Antimicrobial and antioxidant activities of some Nigerian medicinal plants. Afr. J. Trad. Compl. Alt. Med. 4:173-184.

[2] Anroop B, Bhatnagar S.P, Ghosh B and Versha P. "Studies on Occimum gratissimum seed mucilage: evaluation of suspending properties," Indian J Pharm Sci., 2005; 67(2): 206-209.

[3] Austin DJ, Kristinsson KG, Anderson RM (1999). The relationship between the volume of antimicrobial consumption in human communities and the frequency of resistance. Proc Natl Acad Sci USA 96:1152-1156.

[4] Avato P, Bucci R, Tava A, Vitali C, Rosato A, Bialy Z, Jurzysta, M (2006). Antimicrobial activity of saponins from Medicago sp. structure-activity relationship. Phytotherapy Res 20 (6): 454-457.

[5] Balandrin MF, Klocke JA, Wurtele ES, Bollinger WH (1985). Natural plant chemicals: Sources of Industrial and Medicinal materials. Science 228: 1154-1160.

[6] Bharathiraja S, Tholkappian P (2011). AM fungal interaction and its beneficial effects on Crossandra infundibuliformis. International Journal of Current Research 3(6): 100-102.

[7] Camciuc, M., Deplagne, M., Vilarem, G., \& Gaset, A. (1998). Okra-Abelmoschus esculentus (L) Moench $(L)$ MoenchL. (Moench.) a crop with economic potential for set aside acreage in France. Ind Crops and Prod., 7, 257-264.

[8] Funatogawa K, Hayashi S, Shimomura H, Yoshida T, Hatano T, Ito H, Hirai Y (2004). Antibacterial activity of hydrolyzable tannins derived from medicinal plants against Helicobacter pylori. Micro and Immunol 48(4): 251-261 